\title{
Gradual Band Energy to Passivate the Window Layer in Solar Cells
}

\author{
A. Amine*, M. Bouabdellaoui, K. Zaz, Y. Mir, M. Zazoui \\ Laboratory of Condensed Matter and Renewable Energy, Faculty of Sciences and Technology, University of Hassan II Casablanca, \\ Casablanca, Morocco \\ Email: ^aminephy7@yahoo.fr
}

How to cite this paper: Amine, A., Bouabdellaoui, M., Zaz, K., Mir, Y. and Zazoui, M. (2017) Gradual Band Energy to Passivate the Window Layer in Solar Cells. Smart Grid and Renewable Energy, 8, 4651.

http://dx.doi.org/10.4236/sgre.2017.81003

Received: August 23, 2016

Accepted: January 7, 2017

Published: January 10, 2017

Copyright (c) 2017 by authors and Scientific Research Publishing Inc. This work is licensed under the Creative Commons Attribution International License (CC BY 4.0).

http://creativecommons.org/licenses/by/4.0/

\begin{abstract}
The passivation layers at the front of the cell are often referred as to the window layer because it must be transparent so as the solar cell has a high efficiency. In this work, numerical simulation has been proposed to study the effect of the AlGaAs gradual and normal windows on the cell sensitivity to the electron irradiation so as to passivate the solar cell. To expect the effect of gradual window layers, the $\mathrm{J}-\mathrm{V}$ and $\mathrm{P}-\mathrm{V}$ characteristics are confirmed better energy conversion performance of the illuminated solar cells after irradiation. The short circuit current $J_{s c}$ and the open circuit voltage $V_{o c}$ are evaluated for different electron irradiation fluencies. The results show how the gradual window layer improves resistance to electron irradiation through its own parameters.
\end{abstract}

\section{Keywords}

Gradual Window, Electric Field, Degradation, Solar Cell

\section{Introduction}

The main objectives for developing space solar cells are to improve their radiation resistance and high efficiency solar cells. Among compound semiconductor materials, GaAs is widely favoured for space applications due to its excellent conversion efficiency and radiation resistance [1] [2]. Unfortunately, GaAs solar cells suffer from carrier loss due to a high surface recombination velocity. So to reduce front surface recombination losses, one of the more critical design areas is AlGaAs window layer and in order to lessen optical absorption in this layer, high aluminium content alloys are preferred [2] [3]. Normal window layers are quite important in improving and passivising the solar cell energy conversion efficiency. They help in effectively reducing the surface recombination at the 
emitter surface without absorbing the useful light required for the device.

In precedent work, taking into consideration the physics of the window emitter hetero-interface, we have investigated the effect of the normal window layer on solar cells degradation through its own parameters [4] [5]. This new approach which has been proved theoretically and experimentally is used to deduce the relationship between electron and hole minority-carrier lifetime.

This paper is an extension and amelioration to what have been tackled about window and prediction of solar cell device parameters [5]. This is through the numerical simulation by rewriting the calculation principle in solar cells with different window structures, by taking into account the gradual band profile window emitter hetero-interface. Both cells have $\left(\mathrm{Al}_{\mathrm{x}} \mathrm{Ga}_{1-\mathrm{x}} \mathrm{As} / \mathrm{GaAs}\right)-\mathrm{p}+$ type window/emitter, and $\mathrm{n}+$ type collector layers under AM0 illumination and are exposed to $1 \mathrm{MeV}$ electron irradiation. For the sake of investigation, we will display how this effect can contribute to passivating the solar cells. The gradual band structure diagram of cell $\mathrm{p}+-\mathrm{AlGaAs}-\mathrm{p} / \mathrm{n}-\mathrm{GaAs}$ is given in Figure 1 through the parameters, absorption coefficient $\alpha_{W}(\lambda)$ at a given wavelength $\lambda$ and effective hetero-interface recombination velocity $S_{\text {eff }}$ and the field electric due to the gradual band energy of the window layer. The effect of precedent parameters is analysed from studding the variation of short circuit current $J_{S C}$ and the open voltage $V_{O C}$ versus the fluence of the irradiation $\varphi$ [6] [7] [8]. Then, a comparison between both calculated and measured values would be made. Next of great importance is to analogize it with previous work using the normal window layer [5].

When calculating the contribution of each current in different sides of the junction in presence of gradual band window layer, the incident flux $\phi(\lambda)$, and the electron recombination velocity $S_{n}$ should be modified respectively to:

$$
\phi(\lambda) \mathrm{e}^{-\alpha_{w}(\lambda) X_{w}}
$$

And to $S_{\text {eff }}^{n}$ which is expressed as [9] [10]:

$$
S_{e f f}^{n}=S_{n}^{w} \mathrm{e}^{\left(E_{g}-E_{g}^{w} / K_{B} T\right)} \frac{D_{n}^{w} / S_{n}^{w} L_{n}^{w} \tanh \left(X_{w} / L_{n}^{w}\right)+1}{S_{n}^{w} L_{n}^{w} / D_{n}^{w} \tanh \left(X_{w} / L_{n}^{w}\right)+1}
$$

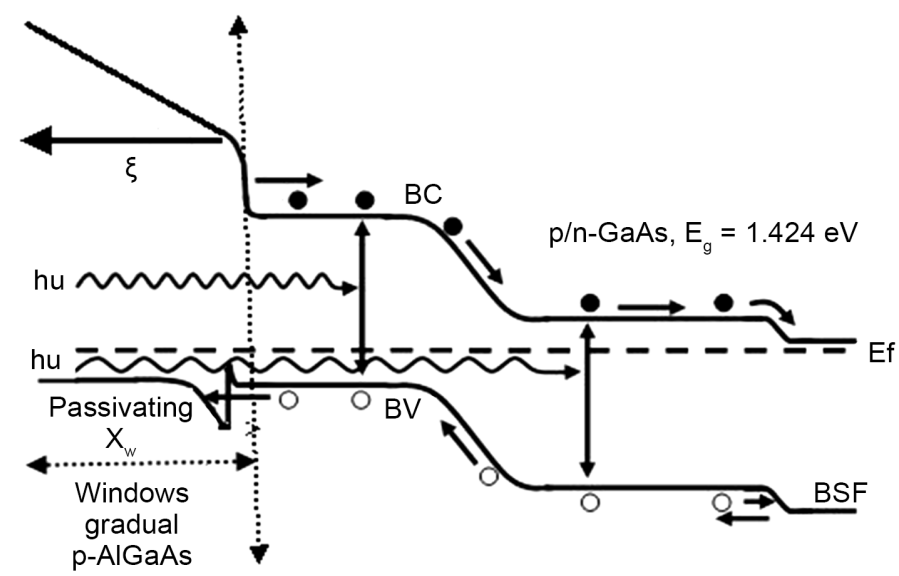

Figure 1. Gradual band structure diagram of cell p-AlGaAs-p/n-GaAs. 
where the absorption coefficient is:

$$
\alpha\left(x_{w}, \lambda\right)=A\left(\frac{h c}{\lambda}-E_{g}^{w}\right)^{1 / 2}
$$

A is a constant depending of choice of semiconductor window, $E_{g}$ and $E_{g}^{w}-q \zeta X_{W}$ are the energy gap in GaAs and in window layer gradual respectively, $q \zeta$ represent the energy of assumed constant band gap where $q$ is the electric charge and $\xi$ is the electric field.

\section{Mechanism of Degradation and Optimization of Windows Layer Parameters}

\subsection{Mechanism of Degradation}

This mechanism made it possible to calculate degradation parameters $\boldsymbol{\tau}_{n o}, \boldsymbol{\tau}_{p o}$, $K \sigma_{n}$ and $K \sigma_{p}$ of $p$ AlGaAs $\mathrm{p}^{+} / \mathrm{n}-\mathrm{GaAs}$ solar cell, just knowing the thickness $X_{w}$ window layer and doping respectively of the emitter and base which are given [4].

The parameters of the studied cell are listed in Table 1 [11].

For the sake of determining the minority carrier lifetimes $\boldsymbol{\tau}_{n o}$ and $\boldsymbol{\tau}_{p o}$ in the $p$ and $n$ regions respectively, it is of paramount importance to know the short circuit current density $J_{s c o}^{\text {exp }}$ and open circuit voltage $V_{o s o}^{\exp }$ measurements under given illumination. In addition, prior irradiation is necessary in order to make the derivation from the initial values of the minority carrier lifetimes and then we inject them into calculation. By so doing along with knowing $J_{s c \varphi}^{\text {exp }}$ and $V_{o s \varphi}^{\exp }$ under given illumination and amount of irradiation $\varphi$ allow it to deduce the values of the minority carrier lifetimes $\tau_{n \varphi}$ and $\tau_{p \varphi}$ to determine $K \sigma_{n}$ and $K \sigma_{p}$; where $K$ is the defect introduction rate, $\sigma_{n}$ and $\sigma_{p}$ are the electron and hole capture cross section. Then from the parameters $\boldsymbol{\tau}_{n o}, K \sigma_{n}$ in emitter and $\boldsymbol{\tau}_{p o}, K \sigma_{p}$ in base, see Table 2, we can determine the variations of the short-circuit currents $J_{s c \varphi}$ and open circuit voltages $V_{o s \varphi}$ versus fluence. More specifically, the degradation parameters, $\boldsymbol{\tau}_{n o}, \boldsymbol{\tau}_{p o}, K \sigma_{n}$ and $K \sigma_{p}$ which fit the experimental data, $J_{s c}^{\text {exp }}$ and $V_{o s}^{\text {exp }}$, are the same for both the short circuit current $J_{s c}^{c a l}$ and the open

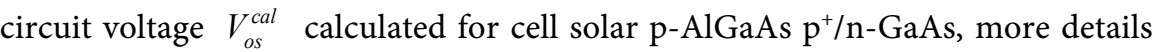
are given in [4] [5].

Table 1. Physical parameter values of $\mathrm{p}-\mathrm{AlGaAs}-\mathrm{p}^{+} / \mathrm{n}-\mathrm{GaAs}$ cell [11].

\begin{tabular}{ccccc}
\hline $\begin{array}{c}\text { Window thickness: } \\
X_{W}\left(10^{-6} \mathrm{~m}\right)\end{array}$ & $\begin{array}{c}\text { Layer emitter: } \\
X_{p}\left(10^{-6} \mathrm{~m}\right)\end{array}$ & $\begin{array}{c}\text { Base thickness: } \\
X_{n}\left(10^{-6} \mathrm{~m}\right)\end{array}$ & $\begin{array}{c}\text { Emitter doping: } \\
N_{A}\left(\mathrm{~cm}^{-3}\right)\end{array}$ & $\begin{array}{c}\text { Base doping: } \\
N_{D}\left(\mathrm{~cm}^{-3}\right)\end{array}$ \\
\hline 0.035 & 0.44 & 3.1 & $1.210^{18}$ & $6.710^{16}$ \\
\hline
\end{tabular}

Table 2. Calculated degradation parameters of $\mathrm{p}-\mathrm{AlGaAs}-\mathrm{p}^{+} / \mathrm{n}-\mathrm{GaAs}$ cell [11].

\begin{tabular}{ccccc}
\hline $\mathrm{p}-\mathrm{AlGaAs} \mathrm{\textrm {p } ^ { + } / \mathrm { n } - \mathrm { GaAs }}$ & $\boldsymbol{\tau}_{n o}(\mathrm{~s})$ & $\boldsymbol{\tau}_{p o}(\mathrm{~s})$ & $K \sigma_{n}(\mathrm{~cm})$ & $K \sigma_{p}(\mathrm{~cm})$ \\
\hline $\begin{array}{c}\text { Degradation } \\
\text { parameters }\end{array}$ & $1.2310^{-11}$ & $1.3710^{-8}$ & $1.1210^{-12}$ & $7.5710^{-14}$ \\
\hline
\end{tabular}




\subsection{Optimization of the Window Layer Parameters}

\subsubsection{Effective Parameter Hetero-Interface Recombination Velocity $S_{\text {neff }}$ Effect}

The degradation parameters, $\boldsymbol{\tau}_{n o}, \boldsymbol{\tau}_{p o}, K \sigma_{n}$ and $K \sigma_{p}$ of the cell $\mathrm{p}-\mathrm{AlGaAs} \mathrm{p}^{+} / \mathrm{n}$ GaAs are added up with the help of our calculation method, and we proceed to study the effects of these parameters. the effective hetero-interface recombination velocity $S_{\text {neff }}$ allows us to know the variation of $J_{S C}$ and $V_{O C}$ versus the fluence of the irradiation $\varphi$, then we can compare between windows p-AlGaAs normal and gradual band where the electric field $\xi=0$ and $\xi=-500 \mathrm{~V} / \mathrm{cm}$ are applied respectively.The degradation is more pronounced when the effective recombination velocity $S_{\text {neff }}$ is smaller. This claim can be justified by the relationship between $S_{\text {neff }}$ and $E_{g W}$ see the expression of $S_{\text {neff }}$ i.e., the increase of $E_{g W}$ leads to the decrease in the $S_{\text {neff }}$ Figure 2(a) shows an important effect on the variation of the $J_{S C}$ under 1 AMO illumination versus the fluence for both values of $S_{\text {neff }}$ This effect remains a little weak on the variation of the $V_{o c}$ parameter as exhibited in Figure 2(b), our design may have the same idea as that of [4] [5].

\subsubsection{Parameter Electric Field $\xi$ Effect}

By comparing the irradiation effect on Cell 1 and Cell 2, where the window layer p-AlGaAs on $\mathrm{p}^{+} / \mathrm{n}-\mathrm{GaAs}$ are normal $(\xi=0)$ and gradual $\left(\xi=-500 \mathrm{~V} \cdot \mathrm{Cm}^{-1}\right)$ respectively, we find that the gradual p-AlGaAs window improves the better resistance to electron irradiation of the short circuit current $J_{s c}$ for the short fluence. This is more clarified in Figure 3(a) which shows the variation of the short circuit current $J_{s c}$ versus the fluence of $1 \mathrm{MeV}$ electron irradiation under $1 \mathrm{AMO}$. Also, thanks to the gradual band profile, the internal electric field $\xi$ caused the accelerating photo-generated of the carriers and thereby enhance their collection efficiency; this electrical field helps to reduce the recombination. By contrast, in

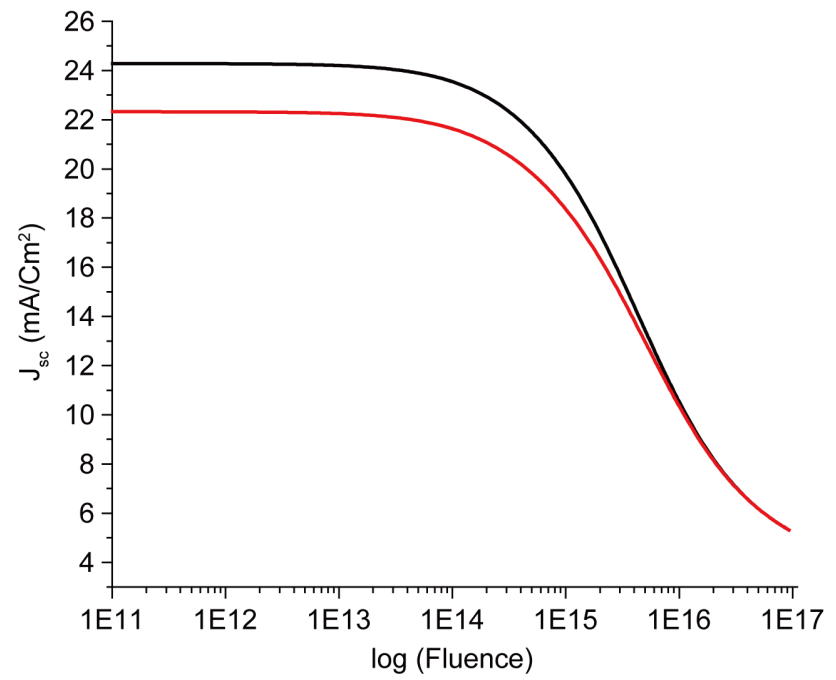

(a)

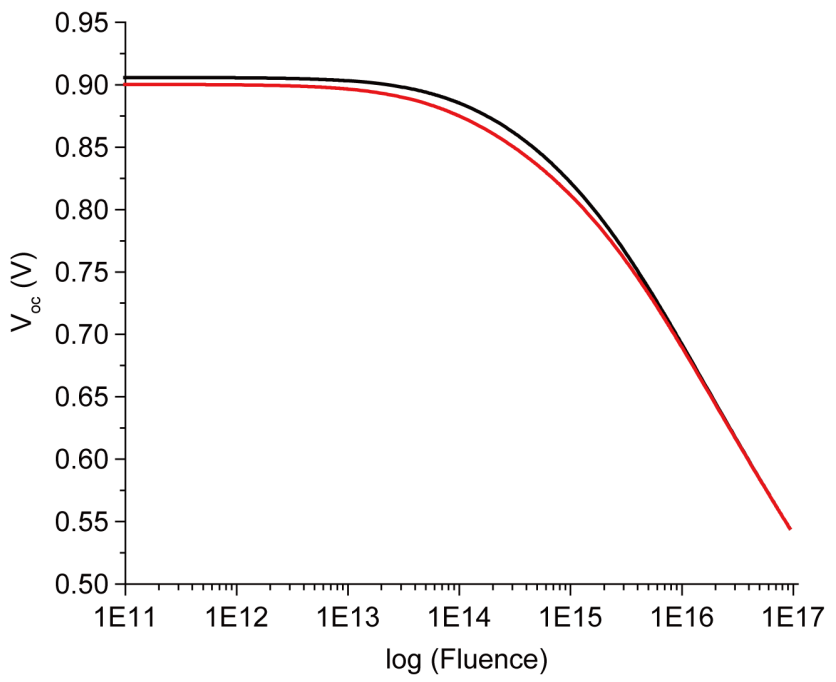

(b)

Figure 2. Variation of the short circuit current $J_{s c}$ (a) and the open circuit voltage $V_{o c}$ (b) under 1 AM0 illumination, versus the fluence of $1 \mathrm{MeV}$ electron irradiation, calculated for both values of $S_{\text {eff }}^{n}=10^{6} \mathrm{~cm} / \mathrm{s}(-)$ and $S_{\text {eff }}^{n}=10^{7} \mathrm{~cm} / \mathrm{s}(-)$ in p-AlGaAs window gradual layer. 


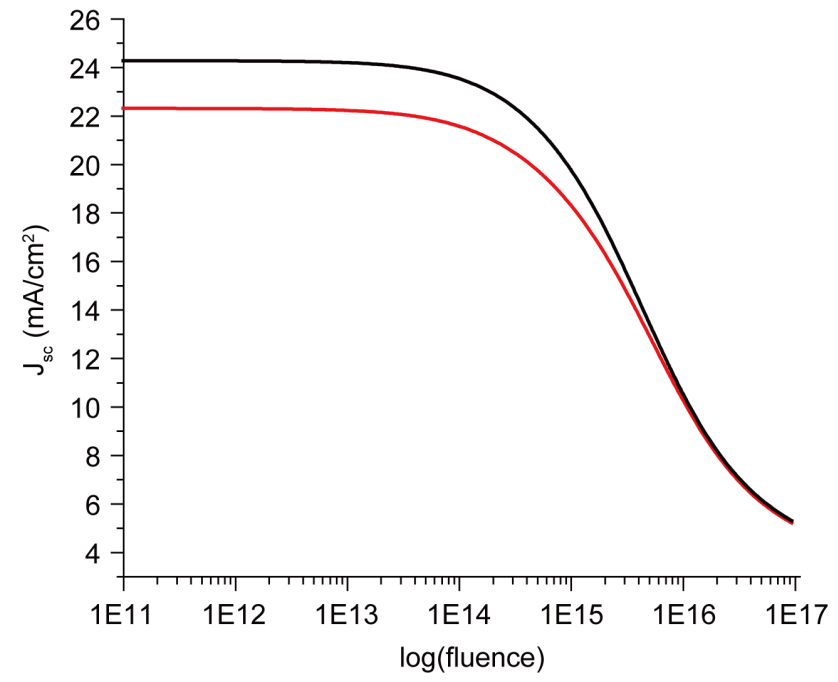

(a)

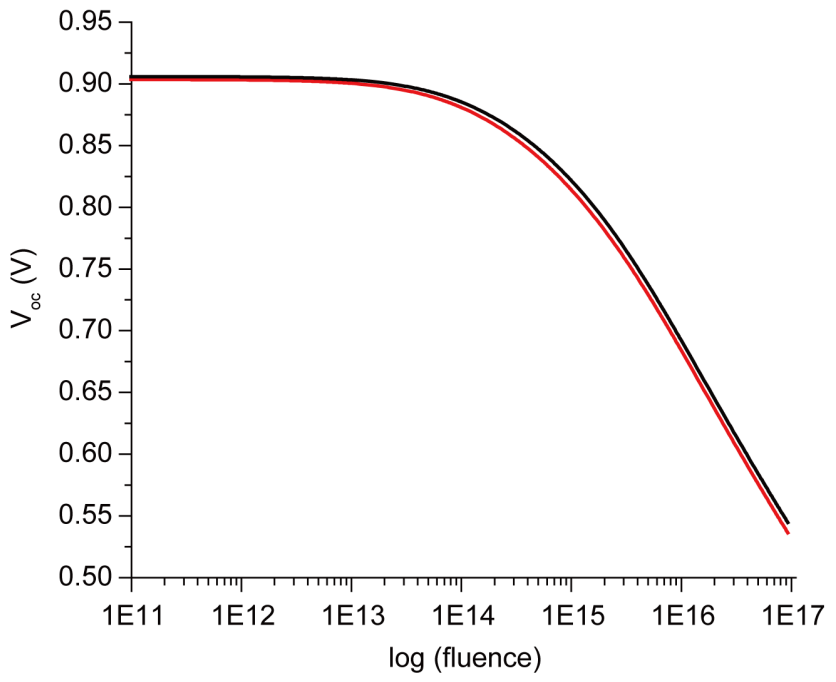

(b)

Figure 3. Variation of the short circuit current $J_{s c}(\mathrm{a})$, and the open circuit voltage $V_{o c}(\mathrm{~b})$, under 1 AM0 illumination, versus the fluence of $1 \mathrm{MeV}$ electron irradiation, calculated for both values of $\xi=-500 \mathrm{~V} / \mathrm{Cm}(-)$ and $\xi=0 \mathrm{~V} / \mathrm{Cm}(-)$ in p-AlGaAs window gradual and normal respectively.

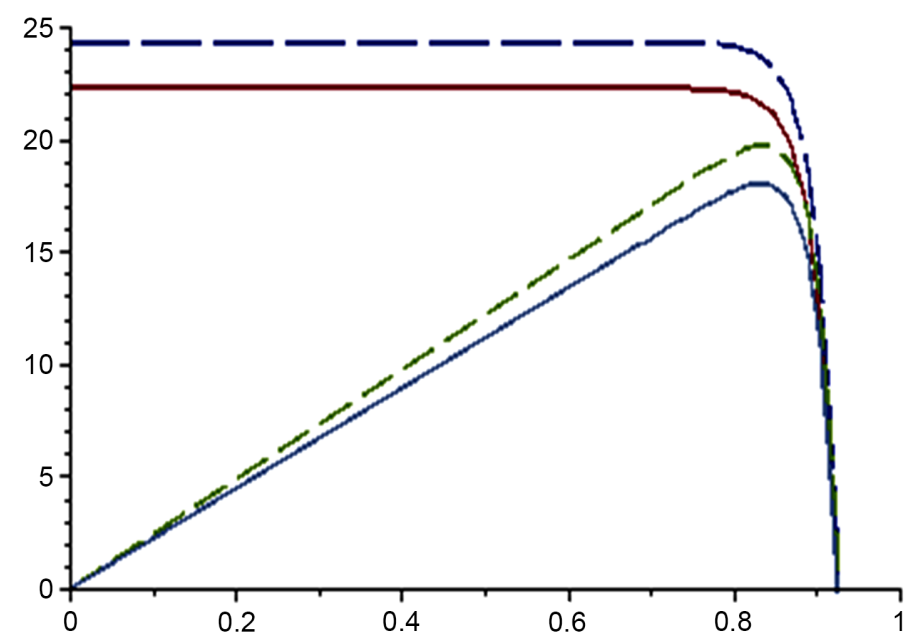

$$
\begin{aligned}
& \text { J-V for normal window }(\xi=0) \\
& - \text { J-V for gradual window }\left(\xi=-500 \mathrm{~V} \cdot \mathrm{Cm}^{-1}\right) \\
& \text { P-V for gradual window }\left(\xi=-500 \mathrm{~V} \cdot \mathrm{Cm}^{-1}\right) \\
& \text { P-V for normal window }(\xi=0)
\end{aligned}
$$

Figure 4. Current density-Voltage $(\mathrm{J}-\mathrm{V})$ and Power-Voltage $(\mathrm{P}-\mathrm{V})$ characteristics of the illuminated solar cells after irradiation by $10^{14} \mathrm{~cm}^{-2}$ electron fluence, calculated for both values of $\xi=-500 \mathrm{~V} / \mathrm{Cm}$ and $\xi=0$ in $\mathrm{p}-\mathrm{AlGaAs}$ gradual and normal windows respectively.

Figure $3(\mathrm{~b})$, the $V_{O C}$ curve exhibits no significant reduction to the different types of the windows, normal and gradual.

From Figure 4 the $\mathrm{J}-\mathrm{V}$ and $\mathrm{P}-\mathrm{V}$ characteristics are confirmed better energy conversion performance of the illuminated solar cells after irradiation by $10^{14}$ $\mathrm{cm}^{-2}$ electron fluence for gradual windows. 


\section{Conclusion}

A modeling of an AlGaAs window/GaAs solar cell, operating under AM0 solar spectrum and exposed to $1 \mathrm{MeV}$ electron irradiation is presented. This is to study the effect of the AlGaAs window on the cell sensitivity to the electron irradiation. In the gradual energy gap AlGaAs window, we have demonstrated that the short circuit current $J_{S C}$ is sensitive to variations of this parameter, but the open voltage $V_{O C}$ remains little sensitive to these variations, so the $\mathrm{p}-\mathrm{AlGaAs}$ gradual window layer structure reduces the surface recombination, and effectively passivates the solar cell. Consequently, the gradual band window layer structure is more effective. Therefore, it is a good candidate for developing the solar cell than normal windows layer.

\section{References}

[1] Jain, R.K. (2003) Photovoltaic Energy Conversion, 2003. Proceedings of 3rd World Conference, 1, 75-78.

[2] Lammasniemi, J., Jain, R.K. and Pessa, M. (1997) Status of Window Layers for III-V Semiconductor Cells. Proceedings of 14th European Photovoltaic Solar Energy Conference, 1767.

[3] Gee, J.M. and Drummond, T.J. (1990) A Theoretical Investigation of Effective Surface Recombination Velocity in AlGaAs/GaAs Heteroface Solar Cells. The 5 th In ternational Photovoltaic Science and Engineering Conference, Kyoto, Japan.

[4] Idali Oumhand, M., Mir, Y. and Zazoui, M. (2009) A New Approach to Determine Accurately Minority-Carrier Lifetime. Physica B, 404, 167-170.

[5] Mir, Y., Amine, A., Bouabdellaoui, M., Zazi, K. and Zazoui, M. (2013) The Window Layers Effect on the Hardness Improvement of Space Solar Cells Exposed to the 1 MeV Electron Irradiations. Optical and Quantum Electronics, 45, 1189-1197. https://doi.org/10.1007/s11082-013-9735-8

[6] Yoshikawa, A. and Kasai, H. (1981) Optimum Design for Window Layer Thickness of GaAlAs-GaAs Heteroface Solar Cell Regarding the Effect of Reflection Loss. Journal of Applied Physics, 52, 43-45. https://doi.org/10.1063/1.329265

[7] Ueda, T., Mohri, M., Gotoh, S., Kakinuma, H. and Akiyama, M. (1998) Improvement of Conversion Efficiency by In0.52 Al0.48 As Window Layers for p+n InP Solar Cells. Solar Energy Materials and Solar Cells, 50, 197-202.

[8] Nakayama, K., Tanabe, K. and Atwater, H.A. (2008) Plasmonic Nanoparticle Enhanced Light Absorption in GaAs Solar Cells. Applied Physics Letters, 93, 121-904. https://doi.org/10.1063/1.2988288

[9] Jain, R.K. and Landis, G.A. (1991) Effect of InAlAs Window Layer on the Efficiency of Indium Phosphate Solar Cells. IEEE Xplore Conference: Photovoltaic Specialists Conference.

[10] Nelson, J. (2003) The Physics of Solar Cells Properties of Semiconductor Materials. Imperial College Press.

[11] Makham, S., Zazoui, M., Sun, G.C. and Bourgoin, J.C. (2005) Non-Empirical Prediction of Solar Cell Degradation in Space. Semiconductor Science and Technology, 20, 699-704. https://doi.org/10.1088/0268-1242/20/8/008 
Submit or recommend next manuscript to SCIRP and we will provide best service for you:

Accepting pre-submission inquiries through Email, Facebook, LinkedIn, Twitter, etc. A wide selection of journals (inclusive of 9 subjects, more than 200 journals)

Providing 24-hour high-quality service

User-friendly online submission system

Fair and swift peer-review system

Efficient typesetting and proofreading procedure

Display of the result of downloads and visits, as well as the number of cited articles Maximum dissemination of your research work

Submit your manuscript at: http://papersubmission.scirp.org/

Or contact sgre@scirp.org 